Abstracta Iranica Abstracta Iranica

Revue bibliographique pour le domaine irano-aryen

Volume 40-41 | 2019

Comptes rendus des publications de 2017-2018

\title{
Peter Zilberg. "From Dragoman to Babel: the role of interpreters in the ancient Near East in the first millennium B.C.E."
}

\section{Astrid Nunn}

\author{
(2) OpenEdition \\ Journals \\ Édition électronique \\ URL : http://journals.openedition.org/abstractairanica/48587 \\ DOI : $10.4000 /$ abstractairanica.48587 \\ ISBN : 1961-960X \\ ISSN : 1961-960X \\ Éditeur : \\ CNRS (UMR 7528 Mondes iraniens et indiens), Éditions de l'IFRI
}

Référence électronique

Astrid Nunn, «Peter Zilberg. "From Dragoman to Babel: the role of interpreters in the ancient Near East in the first millennium B.C.E." », Abstracta Iranica [En ligne], Volume 40-41 | 2019, document 8, mis en ligne le 30 octobre 2019, consulté le 19 avril 2021. URL : http://journals.openedition.org/ abstractairanica/48587 ; DOI : https://doi.org/10.4000/abstractairanica.48587

Ce document a été généré automatiquement le 19 avril 2021

Tous droits réservés 


\title{
Peter Zilberg. "From Dragoman to Babel: the role of interpreters in the ancient Near East in the first millennium B.C.E."
}

\author{
Astrid Nunn
}

\section{RÉFÉRENCE}

Peter Zilberg. "From Dragoman to Babel: the role of interpreters in the ancient Near East in the first millennium B.C.E." in Kyle H. Keimer \& Gillan Davis(eds.). Registers and Modes of Communication in the Ancient Near East. Getting the Message Across. Londre :

Routledge, 2018, p. 193-207

Le titre de cette contribution se réfère à l'article "From Babel to Dragomans", dans lequel son auteur, Bernard Lewis, partait du manque de compréhension entre les humains dans La Genèse pour aboutir au dragoman ottoman. Ici l'A. montre que les interprètes étaient déjà bien représentés au Proche Orient ancien. L'attestation la plus ancienne remonte au Paléodynastique. L'A. liste les attestations dans les textes néoassyriens, néo-babyloniens et achéménides. De nombreuses langues sont en jeu, l'araméen jouant un rôle de plus en plus important. Les interprètes étaient demandés et présents aussi bien à la cour que dans l'administration, dans les temples, lors de voyages, et dans le contact avec des populations étrangères. 


\section{AUTEURS}

\section{ASTRID NUNN}

Université de Munich 